УДК 329.7ОУН(477.64-25)“1940/1943”(045)

DOI: 10.33099/2707-1383-2021-39-1-156-165

Юрій Щур

кандидат історичних наук,

старший викладач

кафедри новітньої історії Украӥни

Запорізький наџіональний університет

(Запоріжжся, Україна)

ORCID: https://orcid.org/0000-0001-7480-4245

Електронна пошта: shchur@zпи.еdu.иа

\title{
ПИТАННЯ ЗБРОЙНОЇ БОРОТЬБИ ДІЯЛЬНОСТІ ОУН НА ЗАПОРІЖЖІ (1940-1943 РР.)
}

\begin{abstract}
У статті проаналізовано проблему підготовки членів Організаиіі украӥнських націоналістів, які діяли на території Запорізької області, до загальноукраїнського повстання. Висвітлено діяльність націоналістичних організачій, зокрема й у військових частинах Червоної армії. 3 'ясовано, щзо серед пріоритетів націоналістичного підпілля на території Запорізької області були збір й накопичення зброї, а також створення в перспективі партизанських загонів. Хронологічно рамки дослідження прив'язані до появи перших осередків ОУН у регіоні (нижня межа) та до піку в діяльності організованого націоналістичного підпілля в області (верхня межа).
\end{abstract}

Ключові слова: Запорізька область, Мелітополь, НКВС, НКДБ, Організаџія украӥнських наџіоналістів.

Постановка проблеми. Розсекречення архівів радянських органів держбезпеки дозволяє більш детально вивчити історію українського націоналістичного руху, зокрема на території Наддніпрянщини. Не в останню чергу це стосується питань, пов'язаних із залученням жителів «підрадянської» України (у конкретному випадку - Запорізької області) до збройної боротьби за незалежність.
Актуальність цієї теми очевидна: вивчення питання збройної боротьби та дотичних проблем на мікрорівні дозволяє, зрештою, деталізувати історію українського націоналістичного руху. Крім того, звертаючи увагу на діяльність націоналістичного підпілля саме на території однієї з областей Півдня України, ми тим самим сприяємо заповненню лакун в новітній історії нашої країни. 
Хронологічно рамки дослідження прив'язані до появи перших осередків Організації українських націоналістів (тут і далі маємо на увазі ОУН, яку очолював С. Бандера) у Запорізькій області (нижня межа) та до піку в діяльності організованого націоналістичного підпілля в регіоні (верхня межа).

Аналіз останніх досліджень та публікацій. Попри доступність архівів радянських спецслужб, тема збройної боротьби в діяльності ОУН на Запоріжжі залишається майже не дослідженою. Автор звертав увагу на цю проблему в загальному контексті історії українського націоналістичного руху в Запорізькій області у 1940-1945 pр. (Щур, Ю. І. 2018). Серед опублікованих джерел виокремимо спогади одного $з$ організаторів мережі ОУН на території Мелітопольської округи І. Молодія (Молодій, І. 1997), серед неопублікованих - архівно-слідчі справи на членів націоналістичного підпілля, які зберігаються в Архівному підрозділі Управління Служби безпеки України в Запорізькій області.

Методологія і методи. Провідними для дослідження стали принципи історизму та об'єктивності. Для досягнення визначеної мети використано комплекс загальнонаукових та спеціальних історичних методів наукового пізнання, зокрема хронологічного та порівняльно-історичного. Методи герменевтики та критичного аналізу історичного джерела були провідними під час аналізу документів радянських органів державної безпеки.

Отже, мета статті полягає у розкритті та узагальненні досвіду підготовки запорізьких осередків Організації українських націоналістів до загальноукраїнського повстання як напередодні німецько-радянської війни, так і під час німецької окупації.

Виклад основного матеріалу дослідження. Питання збройної боротьби за встановлення (відновлення) державної самостійності України займало чільне місце в програмових документах та практиці ОУН. Підпільна організація, створена в умовах військової поразки Української революції та втрати державності, на перше місце ставила саме підготовку загальнонаціонального повстання. Не в останню чергу, зневірившись у чисто політичних (парламентських) формах боротьби. Актуалізація цього напрямку спостерігалася після «золотого вересня» 1939 р., коли для членів ОУН відкрилися можливості щодо більш вільного пересування територією цілої України, а не лише іiі західної частини.

Зокрема, спеціально відібрані члени ОУН із Західної України різними шляхами (екскурсія, працевлаштування тощо) їздили по всій території УРСР й принагідно поширювали серед населення відомості про ідею й завдання Організації (Глід, С. 1955, c. 17). Заарештований органами 
НКВС член Львівського крайового проводу ОУН І. Максимів 23 жовтня 1940 р. у власноручному зізнанні свідчив, що «для піднесення революційних настроїв серед робітництва і селянства на східних областях мала Краєва Екзекутива вислати спеціально деяких членів ОУН - головно робітників і селян до праці в Донбас і інші промислові осередки, щоб там підготовляти повстанчу акцію» (Роман Шухевич в документах радянських органів державної безпеки. 2007, c. 89).

На початку грудня 1940 р. УНКВС Запорізької області було викрито молодіжну антирадянську організацію націоналістичного спрямування, яка діяла у Запоріжжі і мала на меті сприяти відокремленню України від СРСР шляхом організації збройного повстання. Організація, що отримала назву «Самостійна Україна», була створена членом ОУН О. Бойчуком, який прибув до Запоріжжя у квітні 1940 р. в якості завербованого для роботи у тресті «Запоріжбуд» із тодішньої Станіславської області. Співзасновником організації став робітник заводу «Дніпроспецсталь» Г. Лебеденко.

У червні 1940 р. організація нараховувала загалом 12 учасників, із них слідчим УНКВС вдалося встановити та заарештувати 5 осіб: О. Бойчука, Г. Лебеденка, М. Фуглева, М. Понятовського та П. Шестопалку. Мета діяльності гуртка полягала у організації повстання проти радянської влади та створення Української держави. Слушний момент для цього, за словами О. Бойчука, мав настати 3 початком колективізації Західної України, оскільки там у лісах переховується багато українців - старшин польської армії, що чекають такої оказії. До початку розгортання подій на Західноукраїнських землях учасникам «Самостійної України» в Запоріжжі необхідно було шляхом агітації залучати невдоволених радянською владою громадян й готувати повстання. Слідчі УНКВС усерйоз вважали, що «самостійники» займалися збором зброї та готувалися до підриву Дніпрогесу ${ }^{1}$.

Очікуване повстання на Західній Україні не розпочалося, а до кінця жовтня 1940 р. співробітники обласного УНКВС мали достатньо інформації для ліквідації «Самостійної України». Протягом грудня було заарештовано усіх встановлених підпільників. 26 березня 1941 р. відбулося засідання Запорізького обласного суду у справі «Самостійної України». Остаточний вирок було затверджено $з$ таким присудом: Г. Лебеденка й О. Бойчука засуджено до розстрілу 3 конфіскацією майна; М. Фуглева, М. Понятовського та П. Шестопал-

${ }^{1}$ Архівний підрозділ Управління Служби безпеки України в Запорізькій області (далі АП УСБУ 3О). Фонд припинених справ (далі - ФПС). Оп. 1. Спр. П-19824. Т. 1. Конверт. Обвинувальний висновок по слідчій справі № 7072. Арк. 1-5. 
ку — до 10 років таборів й 5-ти ураження в правах ${ }^{2}$.

$\mathrm{У}$ цей же час, крім робітничої молоді, ОУН звертала свою увагу також на студентство, інтелігенцію та військовослужбовців, зокрема на відряджених із Наддніпрянщини для радянізації Західної України. В рамках крайової референтури пропаганди ОУН було створено спеціальні гуртки студентів, які займалися налагодженням контактів із наддніпрянськими однолітками з метою залучення їх до націоналістичного руху (Гривул, Т. 2002, c. 491).

Основною тезою пропагандистської роботи оунівців серед червоноармійців була антинародна й брехлива сутність радянського керівництва. За спогадами бійця 44 стрілкової дивізії С. Старка, серед червоноармійців постійно поширювалися летючки із закликами приєднуватися до націоналістичного руху (Старко, С. 1949, c. 22).

29 червня 1941 р. співробітниками УНКДБ по Запорізькій області була розпочата справа на 11 червоноармійців 31 інженерно-протихімічного батальйону, що дислокувався в обласному центрі. Попередніми слідчими діями було встановлено, що вони створили осередок ОУН у своїй військовій частині наприкінці 1940 р., коли до Запоріжжя прибуло поповнення червоноармійців

2 АП УСБУ ЗО. ФПС. Оп. 1. Спр. П-19824. Т. 3. Конверт. Вирок кримінальний від 1941 року березня 26 дня. Арк. 1-5. із Західної України, зокрема із Львівської області. Організував осередок I. Немировський, який перед виїздом до Запоріжжя отримав від керівника оунівського осередку с. Дунаїв Поморянського району Львівської області І. Попадюка такі завдання:

1) Перебуваючи у Червоній армії виявити членів ОУН, які прибули із Західної України. Повідомляти про останніх своїм організаційним зверхникам та організовуватися для боротьби проти радянської влади.

2) На випадок війни СРСР із будьякою державою, під час бойових дій перейти на сторону останньої й зі зброєю у руках боротися проти Червоної армії.

3) Перебуваючи у тилу Червоної армії у разі початку антирадянського повстання, перейти на сторону повсталих й боротися проти радянської влади за створення Самостійної України.

4) Популяризувати серед військовослужбовців мету й завдання ОУН.

До активу осередку належали також: уродженці Перемишлянського району Львівської області М. Худий та М. Данилів; уродженці Поморянського району тієї ж області М. Цап та В. Жулін.

I. Немировський підтримував письмовий зв'язок із I. Попадюком, від якого отримував інформацію про підготовку оунівців на Західній Україні до антирадянського повстання. Із Запоріжжя надсилалася інформація про стан колгоспів у Запорізькій 
області та проведену роботу серед бійців 31 батальйону. М. Худий листувався із зв'язковою Л. Гловач, від якої також отримував інформацію про підготовку антирадянського повстання ${ }^{3}$.

Ймовірно, однією із причин викриття цього червоноармійського осередку ОУН стало саме це листування. У архівній справі зберігся в якості речового доказу лист Л. Гловач до М. Худого. Тут міститься згадка про 10 заповідей ОУН із деяким цитуванням та повний текст оунівської пісні про В. Біласа й Д. Данилишина ${ }^{4}$. Така інформація просто не могла пройти повз увагу радянських військових цензорів.

На засіданні Військового Трибуналу Запорізького гарнізону Одеського військового округу 12 серпня 1941 p. I. Немировський, М. Худий, М. Цап, В. Жулін та М. Данилів винними себе визнали частково. Не погодилися із обвинуваченням та не визнали себе винними О. Сметана, Г. Іванчишин, М. Панчишин, А. Креховець, В. Вербицький та Г. Нарольський. Згідно з вироком трибуналу, А. Креховця й В. Вербицького визнали виправданими, але присудили до вислання у віддалені області СРСР

3 АП УСБУ ЗО. ФПС. Оп. 1. Спр. П-21902. Обвинувальний висновок по справі № 7394, 31 липня 1941 р. Арк. 198-203.

4 АП УСБУ ЗО. ФПС. ОП. 1. Спр. П-21902. Конверт $з$ речовим доказом. Лист Л. Гловач на адресу М. Худого. Арк. 224. строком на 5 років, інших підсудних засудили до розстрілу 5 .

Створення оунівського осередку та мета його діяльності у 31 батальйоні цілком вкладається у логіку розвитку подій напередодні війни, зокрема плануваннях ОУН. У $\mathrm{IH}_{-}$ струкції Проводу ОУН «Боротьба й діяльність ОУН під час війни» за можливе визнавалося, що під впливом самостійницької пропаганди українці-бійці Червоної армії будуть створювати окремі повстанські відділи для боротьби за незалежність України. Відповідно до військових інструкцій, такі відділи мали бути включені до складу визвольної армії, створеної ОУН. На Наддніпрянщині оунівці не планували виступити всеохоплюючою силою, свою роль вони вбачали як дорадницьку в організації місцевої армії. В «Інструкції щодо Осередніх і Східних українських земель» членам ОУН рекомендувалося проникати до Червоної армії з метою проведення серед військовослужбовців антирадянської самостійницької пропаганди (Українське державотворення. 2001, с. 21-23).

Більш предметно до питання збройної боротьби на території Запорізької області членам ОУН випала нагода підійти під час німецько-радянської війни. Зокрема, серед го-

АП УСБУ ЗО. ФПС. ОП. 1. Спр. П-21902. Вирок Військового Трибуналу Запорізького гарнізону Одеського військового округу 12 серпня 1941 р. Арк. 207, 212 зв.-213, 222 3в.-223, 228-228 зв. 
ловних напрямків діяльності під час німецької окупації було накопичення сил й підготовка до загальнонаціонального повстання. В цьому плані також передбачалося здійснювати збір й магазинування зброї. Зокрема, виконуючи настанови керівництва Запорізького обласного проводу ОУН, підпільники з Михайлівського району збирали вогнепальну зброю. За iii переховування відповідальним був член обласного проводу ОУН, референт Служби безпеки Б. Крицан («Криця»). Він з допомогою місцевого жителя Ф. Герасименка відвозив зброю й боєприпаси до плавнів Великого Лугу6.

Наявність у михайлівських націоналістів значного арсеналу зброї відмічали і керівники місцевого радянського підпілля. Зокрема, К. Шершнєв інформував С. Горлова, що зброю для антинацистської діяльності можна отримати у місцевих оунівців, серед керівництва яких згадувалися М. Коломоєць та М. Іванніков. На заваді переговорів про отримання зброї і можливу співпрацю стали нацистські репресії проти активістів михайлівської ОУН (Запорізький архів. Народна війна. 2005, c. 345-346).

Агент радянських органів держбезпеки Кульчицький навесні 1943 р. від оунівця з Михайлівки П. Письме-

${ }^{6}$ Державний архів Запорізької області. Ф. Р 5747. Оп. 3. Спр. 7560. Протокол допиту обвинуваченого Фесенка Олександра Кириловича від 18 лютого 1944 року. Арк. 53. ного дізнався про спроби Запорізького обласного проводу ОУН організувати в регіоні націоналістичний партизанський відділ чисельністю близько 200 осіб. Аналогічний загін планувалося створити також і в Михайлівському та сусідньому Великобілозерському районах. Пізніше П. Письмений розповів Кульчицькому, що задум з організації партизанських загонів не був реалізований через початок масових арештів оунівців німецькими органами держбезпеки по всій території області ${ }^{7}$.

У Мелітополі також проводилася робота із накопичення зброї. За свідченнями оунівця Ю. Курила, одним із відповідальних за придбання зброї був його батько, член Мелітопольського окружного проводу ОУН I. Курило-Кримчак. Останній, зокрема, мав у користуванні два пістолети: наган й «один німецького виробництва» ${ }^{8}$. Крім того, завдання щодо організації ресурсів для купівлі зброї від члена Запорізького обласного проводу ОУН Б. Мовчана («Степана Лисавки») отримав окружний провідник Л. Сухіно-Фоменко («Кривоніс»). Користуючись своїм службовим становищем головного технолога горіл-

\footnotetext{
${ }^{7}$ Галузевий державний архів Служби безпеки України. Ф. 2. Оп. 93. Спр. 26. Доповідь про виконану агентурно-оперативну роботу відділу ББ УНКВС по Запорізькій області за січень місяць 1944 року. Арк. 4.

8 АП УСБУ ЗО. ФПС. Оп. 1. Спр. П-19379. Протокол допиту обвинуваченого Курило Юрія Іларіоновича від 3 березня 1945 р. Арк. 30.
} 
чаного заводу, останнім мав дістати (вкрасти на заводі) горілку й продати іiі. На частину виручки треба було придбати п'ять пістолетів. За зброєю мав прибути кур'єр зі словами: «Я приїхав із Запоріжжя від Степана Лисавки за пакетом» й опісля цього сказати кодове слово: «Курган». Відповідь Л. Сухіно-Фоменка мала бути «Могила». Виконуючи вказані настанови, на заводі було викрадено 15 літрів горілки й на частину отриманих за неї грошей придбано у словацьких солдат п'ять автоматичних семизарядних пістолетів із набоями, які були особисто передані Б. Мовчану 9 .

Зауважимо, що Б. Мовчан був ініціатором створення на базі мелітопольського націоналістичного підпілля партизанського відділу в кількості 50 осіб в районі Молочного лиману. За спогадами I. Молодія, він отримав завдання задля реалізації цього напрямку тримати зв'язок із місцевою прорадянською організацією та співпрацювати із нею в питаннях антинацистської діяльності. Від них же мала бути передана зброя. Ідея створення партизанського відділу не знайшла підтримки у керівництва мелітопольського націоналістичного підпілля (М. Вінтоніва, І. Молодія, Л. Сухіно-Фоменко) (Молодій, I. 1997 , c. $85-86)$.

9 АП УСБУ ЗО. ФПС. Оп. 1. СПр. П-19344. T. 1. Протокол допиту обвинуваченого Сухіно-Фоменка Леоніда Іоновича від 22 грудня 1943 р. Арк. 19-19 зв.
Попри неоднозначне ставлення до питання взаємодії із прорадянським підпіллям, остання таки мала місце. Восени 1943 р. оунівець О. Шевченко, за дорученням I. Курила-Кримчака, провів переговори з рядом лідерів прорадянських загонів, зокрема В. Лукашевим 3 Приазовського, П. Івненком та О. Ліхініним $3 \mathrm{Me}-$ літопольського районів. Більшу активність у переговорах з націоналістами проявив О. Ліхінин, який взяв участь у оунівській нараді в с. Вознесенка Мелітопольського району. Було досягнуто домовленості про об’єднання зусиль загону О. Ліхініна й групи ОУН у майбутньому збройному виступі проти німців. На заваді подальших об'єднавчих процесів став ще один діяч прорадянського підпілля А. Шестопьоров (Запорізький архів. Народна війна. 2005, с. 336-338).

У тому ж Мелітопольському районі був зафіксований випадок прямого бойового зіткнення членів ОУН 3 нацистськими спецслужбами. 11 квітня 1943 р. в с. Костянтинівка в хаті оунівця агронома П. Шевченка проходила нарада за участі членів обласного проводу. Близько 21-ї години вони були оточені гестапо. В «мішку» опинилися керівник міського проводу М. Вінтонів, члени обласного проводу Б. Мовчан й Б. Крицан, господар та його родина. На вимогу гестапо здатися, оунівці розпочали стріляти. Внаслідок перестрілки зі сторони 
німців було троє вбитих. Зі сторони оунівців втрати були більш значні: загинули обидва члени обласного проводу, господар хати, його дружина й діти. М. Вінтонів отримав важке поранення в голову й через два дні помер у в'язниці від тортур. По дорозі на нараду до Костянтинівки були заарештовані керівники ОУН Мелітопольської округи М. Сливка («Буревій») та Л. Сухіно-Фоменко (Молодій, І. 1997, с. 89-92).

Після повернення восени 1943 p. радянської влади на територію Запорізької області органи держбезпеки протягом наступних 2-3 років провели «зачистку» регіону від учасників та прихильників українського націоналістичного руху. 3 того часу на території області ОУН не вдалося створити мережу широко розгалуженого підпілля. Час від часу, виникали окремі організації, або глибоко законспіровані осередки ОУН. Матеріалів щодо планів зі створення партизанських відділів або здійснення збройних акцій на сьогоднішній день не знайдено.

Висновки дослідження. Таким чином, можемо зробити певні висновки і зауваження. Напередодні та під час німецько-радянської війни осередки ОУН на території Запорізької області були залучені до загальноорганізаційної діяльності з підготовки збройного повстання, яке мало призвести до створення незалежної української держави. У 1940-1941 рр. це мало бути антирадянське повстання, початок якого мав співпасти з початком суцільної колективізації на території Західної України. Під час німецької окупації у 1941-1943 рр. члени ОУН одночасно виступали як проти нацистської, так і проти радянської влади. Для цього періоду характерним $є$ очікування ослаблення однієї з протиборчих сторін, що дозволило $б$ реалізувати плани націоналістів. Тим часом, члени ОУН накопичували зброю й готувалися до створення партизанських відділів.

\section{СПИСОК ВИКОРИСТАНИХ ДЖЕРЕЛ ТА ЛІТЕРАТУРИ}

Глід, С. (1955). Фрагменти життя і мук: Спогади з часів німецької окупаџї України. Лондон: Спілка українців Британії, 92 с.

Гривул, Т. (2002). Підготовка Організації Українських Націоналістів до створення національних збройних сил (1939-1941). Народознавчі зошити. № 5-6, с. 487-492.

Запорізький архів. Народна війна. 1941-1944. Антифашистський рух Опору на території Запорізької області: Збірник документів і матеріалів. Авт.-упоряд.: В. О. Бондар, О. Г. Величко, І. В. Козлова. Запоріжжя: Прем'єр. 2005, 560 с.

Молодій, І. (1997). Пискоровичі, Пискоровичі ... моя любов, моє горе. Закерзоння. Спомини вояків УПА. Підготував Б. Гук. Варшава: Тирса. Т. 3, с. 7-248. 
Роман Шухевич у документах радянських органів державної безпеки (1940-1950). (2007). В 2 т. Т.1. 2007. Упоряд. В. Сергійчук та ін. К.: ПП Сергійчук М. I., 640 с.

Старко, С. (1949). Слідами смерти. Самостійна Украӥна. № 7-8, с. 22-26.

Українське державотворення. Акт 30 червня 1941 р. Збірник документів і матеріалів. (2001). Упоряд. О. Дзюбан. Львів; К.: Літературна агенція «Піраміда», 557 с.

Щур, Ю. (2018). ОУН на території Запорізької області. 1940-1945. Документи і матеріали. Літопис УПА. Серія «Бібліотека». Т. 14. Торонто; Львів: Видавництво «Літопис УПА», $648 \mathrm{c}$.

\section{REFERENCES}

Hlid, S. (1955). Frahmenty zhyttia i muk: Spohady z chasiv nimets'koi okupatsii Ukrainy [Fragments of life and torment: Memories from the time of the German occupation of Ukraine]. London: Spilka ukraintsiv Brytanii, 92 s. [in Ukrainian].

Hryvul, T. (2002). Pidhotovka Orhanizatsii Ukrains'kykh Natsionalistiv do stvorennia natsional'nykh zbrojnykh syl (1939-1941) [Preparation of the Organization of Ukrainian Nationalists for the Creation of National Armed Forces (1939-1941)]. Narodoznavchi zoshyty. № 5-6, s. 487-492. [in Ukrainian].

Zaporiz'kyj arkhiv. Narodna vijna. 1941-1944. Antyfashysts'kyj rukh Oporu na terytorii Zaporiz'koi oblasti: Zbirnyk dokumentiv i materialiv [Zaporozhye archive. People's war. 19411944. Anti-fascist Resistance movement in the Zaporozhye region: A collection of documents and materials]. Avt.-uporiad.: V. O. Bondar, O. H. Velychko, I. V. Kozlova. Zaporizhzhia: Prem'ier. (2005), 560 s. [in Ukrainian].

Molodij, I. (1997). Pyskorovychi, Pyskorovychi ... moia liubov, moie hore [Piskorovichi, Piskorovichi... my love, my grief]. Zakerzonnia. Spomyny voiakiv UPA. Pidhotuvav B. Huk. Varshava: Tyrsa. T. 3, s. 7-248. [in Ukrainian].

Roman Shukhevych u dokumentakh radians'kykh orhaniv derzhavnoi bezpeky (1940-1950). (2007). [Roman Shukhevych in the documents of the Soviet state security bodies (1940-1950)]. V 2 t. T. 1. Uporiad. V. Serhijchuk ta in. K.: PP Serhijchuk M. I., 640 s. [in Ukrainian].

Starko, S. (1949). Slidamy smerty [Traces of death]. Samostijna Ukraina. № 7-8, s. 22-26. [in Ukrainian].

Ukrains'ke derzhavotvorennia. Akt 30 chervnia 1941 r. Zbirnyk dokumentiv i materialiv. (2001). [Ukrainian state formation. Act of June 30, 1941. Collection of documents and materials]. Uporiad. O. Dziuban. L'viv; K.: Literaturna ahentsiia "Piramida", 557 s. [in Ukrainian].

Schur, Yu. (2018). OUN na terytorii Zaporiz'koi oblasti. 1940-1945. Dokumenty i materialy [OUN in the Zaporozhye region. 1940-1945. Documents and materials]. Litopys UPA. Seriia “Biblioteka”. T. 14. Toronto; L’viv: Vydavnytstvo "Litopys UPA”, 648 s. [in Ukrainian]. 


\section{Yuri Shchur}

Candidate of Historical Sciences, senior lecturer of the Contemporary History

of Ukraine Department

Zaporizhzhia National University

(Zaporizhzhia, Ukraine)

ORCID: https://orcid.org/0000-0001-7480-4245

\section{ARMED STRUGGLE ISSUES OF THE OUN ACTIVITY IN ZAPORIZHZHIA (1940-1943)}

The article reveals the preparational processes for an all-Ukrainian uprising of the Organisation of Ukrainian Nationalists (OUN) after the Western Ukraine accession to the Ukrainian SSR. The author pays significant attention to the events, which occurred in the Zaporizhzhia region within the units of the Red Army. The research also demonstrates how, among the Red Army, the OUN implemented their all-military activity in one of the military Units in Zaporizhzhia.

The author shows the aspects of the realisation processes regarding the military direction of the OUN centres on the territory of the modern Zaporizhzhia region, which took place during the German occupation. It was stated that the main priorities of the activity were collecting and accumulating armaments that would have provided functioning of later guerrilla units. The creation of such a unit and provision of its fundamental activity was prioritised for Melitopol district and Zaporizhzhia oblast OUN authorities in the first quarter of 1943. Similar activity did not go unnoticed. Therefore, the Soviet secret services directed their special agents for reconnaissance and surveillance.

In several Zaporizhzhia districts (particularly Melitopol) and modern Kherson oblasts, the Ukrainian nationalists managed to cooperate with anti-Nazi guerrilla units, which used to follow communist views.

Despite the majority of scientific research regarding the OUN activity in Zaporizhzhia, the lower chronological limit is supposed to be 1940. However, the author suggests considering 1940 instead. The author explains that the first OUN formations in Zaporizhzhia appeared the year before the German-Soviet war. The upper chronological limit of the research is a peak activity of an organised nationalist movement in Zaporizhzhia oblast about the armed struggle.

Keywords: Melitopol, NKGB (People's Commissariat for State Security), NKVD (People's Commissariat for Internal Affairs), OUN (Organisation of Ukrainian Nationalists), Zaporizhzhia oblast. 